\title{
KURUMSAL SOSYAL SORUMLULUK: KAVRAMSAL BİR BAKIȘ
}

Ozan BÜYÜKYILMAZ

Yahya FIDAN $^{2}$
Başvuru Tarihi: 05.10.2015

Kabul Tarihi: 10.11.2015

\section{$\ddot{O} Z$}

Kurumsal sosyal sorumluluk, işletmeler tarafindan yasal beklentilerin de ötesine giderek ve gönüllü olarak toplumsal ve çevresel refahın arttırılması için gerçekleştirilen faaliyetleri kapsamaktadır. Bu çalışmada kurumsal sosyal sorumluluk kavramı, tanım ve kapsam, sosyal sorumluluk teorileri, işletmelerin sosyal sorumluluk faaliyetlerine yönelme nedenleri ve sosyal sorumluluk alanlart kapsamında incelenmektedir. Çalışma ile kurumsal sosyal sorumluluk literatürüne katkı sağlamak amaçlanmaktadır.

Anahtar Kelimeler: Kurumsal Sosyal Sorumluluk, Sosyal Sorumluluklar, Sosyal Sorumluluk Alanı Jel Sinıflandırması: M14

\section{CORPORATE SOCIAL RESPONSIBILITY: A CONCEPTUAL OVERVIEW}

\section{ABSTRACT}

Corporate social responsibility includes the activities performed by enterprises that going beyond the legitimate expectations and carried out on a voluntary basis to improve the social and environmental well-being. In this study, the concept of corporate social responsibility is examined within the frame of definition and content, social responsibility theories, causes that enterprises are moving to social responsibility activities and the scope of social responsibility. It is intended to contribute to the literature of corporate social responsibility with this study.

Keywords: Corporate Social Responsibility, Social Responsibilities, Scope of Social Responsibility Jel Classification: M14

\footnotetext{
${ }^{1}$ Yrd. Doç. Dr., Karabük Üniversitesi, İşletme Fakültesi, ozanbuyukyilmaz@karabuk.edu.tr

${ }^{2}$ Prof. Dr., Karabük Üniversitesi, İşletme Fakültesi, yahyafidan@karabuk.edu.tr
} 


\section{GİRIŞ}

İşletmeler ile toplum arasındaki ilişki çok uzun yıllardır tartışılan bir konudur. Bu kapsamda araştırmacıların, 1950'li yıllardan beri, işletmelerin topluma karşı sorumlulukları ile ilgili kavram ve teorilere odaklandığı görülmektedir. 1960'lı yıllarda kurumsal sosyal sorumluluk, işletmenin ekonomik ve teknik ihtiyaçlarının en azından kısmen ötesine geçen karar ve faaliyetler olarak tanımlanmaktaydı (Davis, 1960:70). Günümüzde ise kurumsal sosyal sorumluluk, yalnızca ekonomik büyümenin değil, sosyal ve çevresel gelişimin de sürekli k1lınabilmesi için faaliyetlerin etik yollarla gerçekleştirilmesi anlamına gelmektedir. Bu bakımdan da, günümüz iş dünyası için yeni olmayan fakat önemi giderek artan bir kavram durumundadır (Hennigfeld vd., 2006:117).

Kurumsal sosyal sorumlulukların öneminin artmasında farklı unsurların etkisinin varlığından söz edilebilir. Çevre kirliliği, sanayi atıkları ve gazlarının yoğunluğu ve doğanın tahribinin yol açtığı küresel ısınma şayet önlem alınmaz ise dünyanın yok oluşuna kadar gidebilecek senaryoları gündeme getirmekte ve toplumların bu konulardaki duyarlılığının artışına yol açmaktadır.

Diğer taraftan müşteriler giderek daha bilinçli ve toplumsal sorumluluklara karşı duyarlı hale gelmektedir. Öyle ki müşteriler, işletmelerin sosyal sorumluluklarına duyarlılıklarını yakından izlemekte ve sorumluluklarına duyarlı işletmelerin mal ve hizmetlerini tercih etmek suretiyle işletmeleri "ödüllendirmekte" ya da tercih etmeyerek bir nevi "cezalandırmakta"dır. Fiyat ve kalite açısından benzerlik gösteren iki üründen, birinin tercih edilmesinde ürün bedelinin bir bölümünün sosyal bir amaç için harcanması etkili olmaktadır. Hatta bu husus işletmelerin, ürün etiketlerine "bu ürünün· üretiminde çocuk emeğinden yararlanılmamıştır", "bu ürün için ne çocuk ne de köle işgören çalıştırılmıştır" gibi ibareler koymalarına sebep olmaktadır. Toplumun işletmelerden beklentileri ise çevreye zarar vermemeleri, üretim zincirinde sorumlu, duyarlı tedarikçilerle çalışılması ve çalışanlara adil davranılması konularında somutlaşmaktadır (Ersöz, 2007:13-14).

Kavramın öneminin artmasında ayrıca, iş dünyasında ortaya çıkan skandallar (Enron, WorldCom, Parmalat, Qwest, ImClone, vb.) ile birlikte müşterilerin işletmelere, liderlere ve ekonomiye olan güvenlerinin sarsılmasının ve bunun sonucunda "iş ahlakı" ve "kurumsal yönetim" gibi konulara daha fazla ilgi gösterilmesinin etkili olduğu söylenebilir. Ayrıca çeşitli uluslararası kuruluşlar (Birleşmiş Milletler, OECD, ILO, Avrupa Birliği) liderliğinde insan haklarına, çevreye, çalışan işgücüne yönelik korumacı yaklaşımlar ve bu konuda geliştirilen 
standartlar, işletmelerin kurumsal sosyal sorumluluk konusunda daha ihtiyatlı davranmaları gerekliliğini ortaya koymaktadır (Aktan ve Börü, 2007:11).

\section{KURUMSAL SOSYAL SORUMLULUĞUN TANIMI VE KAPSAMI}

Sorumluluk "kişinin kendi davranışlarını veya kendi yetki alanına giren herhangi bir olayın sonuçlarını üstlenmesi, sorum, mesuliyet" anlamına gelmektedir (TDK, 2015). İşletmelerin de tıpkı bireyler gibi içinde bulunduğu toplum, ülke ve uluslararası çevre bağlamında sosyal ve ekonomik sorumlulukları bulunmaktadır. Bu nedenle davranışlarını toplumsal sonuçlarını gözeterek gerçekleştirmek durumundadırlar (Vural ve Coşkun, 2011:62).

En geniş şekilde kurumsal sosyal sorumluluk, işletmeler, ülke yönetimleri ve vatandaşlar arasındaki ilişkileri kapsayan bir kavram iken, daha dar olarak bakıldığında ise bir işletme ile bu işletmenin bulunduğu ve faaliyetlerini gerçekleştirdiği çevre arasındaki ilişkileri ifade etmektedir (Crowther ve Aras, 2008:7; Roberts, 1992:595). Fakat kurumsal sosyal sorumluluk farklı şekillerde tanımlanabilmekte ve kavramın anlamı üzerinde fikir birliği bulunmamaktadır.

Avrupa Birliği Komisyonu'nun tanımına göre kurumsal sosyal sorumluluk, işletmelerin gönüllü olarak toplumsal ve çevresel sorunlarını, faaliyetleriyle ve paydaşlarıyla olan ilişkileriyle bütünleştirmesini içeren bir kavramdır. Bu çerçevede sosyal sorumluluk yalnızca yasal beklentilerin yerine getirilmesi anlamına gelmemekte, bunun da ötesine geçerek insan sermayesine, çevreye ve paydaşlarla ilişkilere daha fazla yatırım yapılmasını gerekli k1lmaktadır (Commission of the European Communities, 2001:6).

Jones (1980:59-60)'a göre kurumsal sosyal sorumluluk, işletmelerin, hissedarlarıyla birlikte toplumun diğer gruplarına karşı kanun veya sendikal sözleşmelerle açıklananın dışında da yükümlülüklerinin bulunmasıdır. Bu tanım çerçevesinde, yükümlülüklerin gönüllü olarak kabul edilmesi ve işletmenin yalnızca hissedarlara karşı değil, müşterilerine, çalışanlarına, tedarikçilerine ve rakiplerine karşı da sorumlu olması şeklinde iki özellik ön plana çıkmaktadır.

Kotler ve Lee (2005:3) benzer bir tanım yapmakta ve kurumsal sosyal sorumluluğu, "işletmelerin faaliyetleri ve kurumsal kaynakları aracılığıyla toplum refahının arttırılması için gönüllü olarak üstlenmiş oldukları yükümlülükler" şeklinde ifade etmektedir. Kurumsal sosyal sorumluluklar kapsamında işletmelerin üstlenmiş olduğu yükümlülükler, yasal veya ahlaki nedenlerden dolayı değil gönüllülük esası ile yerine getirilmektedir. Bu çerçevede işletmelerin katkıları, nakit destekler, hibeler, ücretli reklam, tanıtım, sponsorluk, teknik destek, ayni yardım, çalışan gönüllülüğü ve dağıtım kanallarına erişim gibi farklı şekillerde ortaya çıkabilmektedir. 
Bir başka tanıma göre ise kurumsal sosyal sorumluluk, işletmenin çıkarlarının ötesinde daha fazla sosyal faydanın ortaya çıkartılabilmesi için yasal zorunluluklardan da fazla olarak gerçekleştirilen faaliyetler olarak tanımlamaktadır. Dolayısıyla kurumsal sosyal sorumluluk kurallara uymaktan da fazlasını yapmak anlamına gelmektedir (McWilliams ve Siegel, 2001:117; McWilliams vd., 2006:1).

Adeyeye (2012:7) kurumsal sosyal sorumluluk kavramının sosyal konularda gerçekleştirilen yanlış kurumsal davranışlara (çevre, işçi ve insan hakları ihlalleri) dikkat çekme ihtiyacından doğduğunu belirtmektedir. Bu bakış açısından kurumsal sosyal sorumluluk, işletmenin sosyal konularda gerçekleştirdiği gönüllü eylemleri ifade etmektedir. Bu çerçevede işletmeler, sosyal sorumluluk faaliyetlerini yerine getirdiklerini ve benimsediklerini göstermek amacıyla, kavram ile ilişkili birçok kural, politika ve uygulama geliştirmektedir.

Carroll (1991:40-43), kurumsal sosyal sorumluluk kavramını bir piramidin bölümleri şeklinde ele almaktadır. Bu çerçevede kurumsal sosyal sorumluluğun piramidin altından üstüne doğru dört tip sorumluluğu kapsadığını belirtmektedir. Bunlar;

-Ekonomik sorumluluklar: Her şeyden önce işletmeler, toplumdaki temel ekonomik birimlerdir. Dolayısıyla temel görevleri, tüketiciler tarafından ihtiyaç duyulan ürün ve hizmetleri üretmek ve bu süreçte kabul edilebilir bir kâr elde etmektir. Ekonomik sorumluluk yerine getirilmeden diğer tüm sorumlulukların tartışmalı hale geleceğinden dolayı, işletmenin diğer tüm sorumluluklarının temelinde ekonomik sorumluluk yer almaktadır.

-Yasal Sorumluluklar: İşletmelerin yalnızca kâr amacıyla faaliyetlerini yerine getirmesi değil, aynı zamanda devlet veya yerel yönetimler tarafindan oluşturulmuş yasalara ve yönetmeliklere de uygun hareket etmesi beklenmektedir. İşletme ve toplum arasındaki sosyal sözleşmenin kısmen de olsa sağlanabilmesinde, ekonomik faaliyetlerde hukuka uygunluk önemli bir koşuldur. Bu çerçevede yasal sorumluluk, ekonomik sorumluluktan sonra ikinci aşamayı oluşturmaktadır.

-Etik (ahlaki) sorumluluklar: Ekonomik ve hukuki sorumlulukların hakkaniyet ve adalet gibi etik normları somutlaştırmasına rağmen etik sorumluluklar, hukuk kuralları tarafından kodlanmamış, fakat toplum üyeleri tarafından beklenen veya istenmeyen faaliyet ve uygulamalardan oluşmaktadır. Etik sorumluluklar, tüketiciler, çalışanlar, hissedarlar ve toplum tarafından adil olarak kabul edilen standartları, normları ve beklentileri kapsamaktadır.

-Gönüllü sorumluluklar: Gönüllü sorumluluk, işletmenin iyi bir kurumsal vatandaş olması şeklindeki toplumsal beklentilerin karşılanması amacıyla gerçekleştirilmesi gereken kurumsal faaliyetleri kapsamaktadır. Bu çerçevede işletmenin, insanların refahının ve iyiliğinin arttırılması için gerçekleştirilen faaliyet ve programlara aktif katılımı gerekli olmaktadır. 


\section{Şekil 1. Kurumsal Sosyal Sorumluluklar Piramidi}

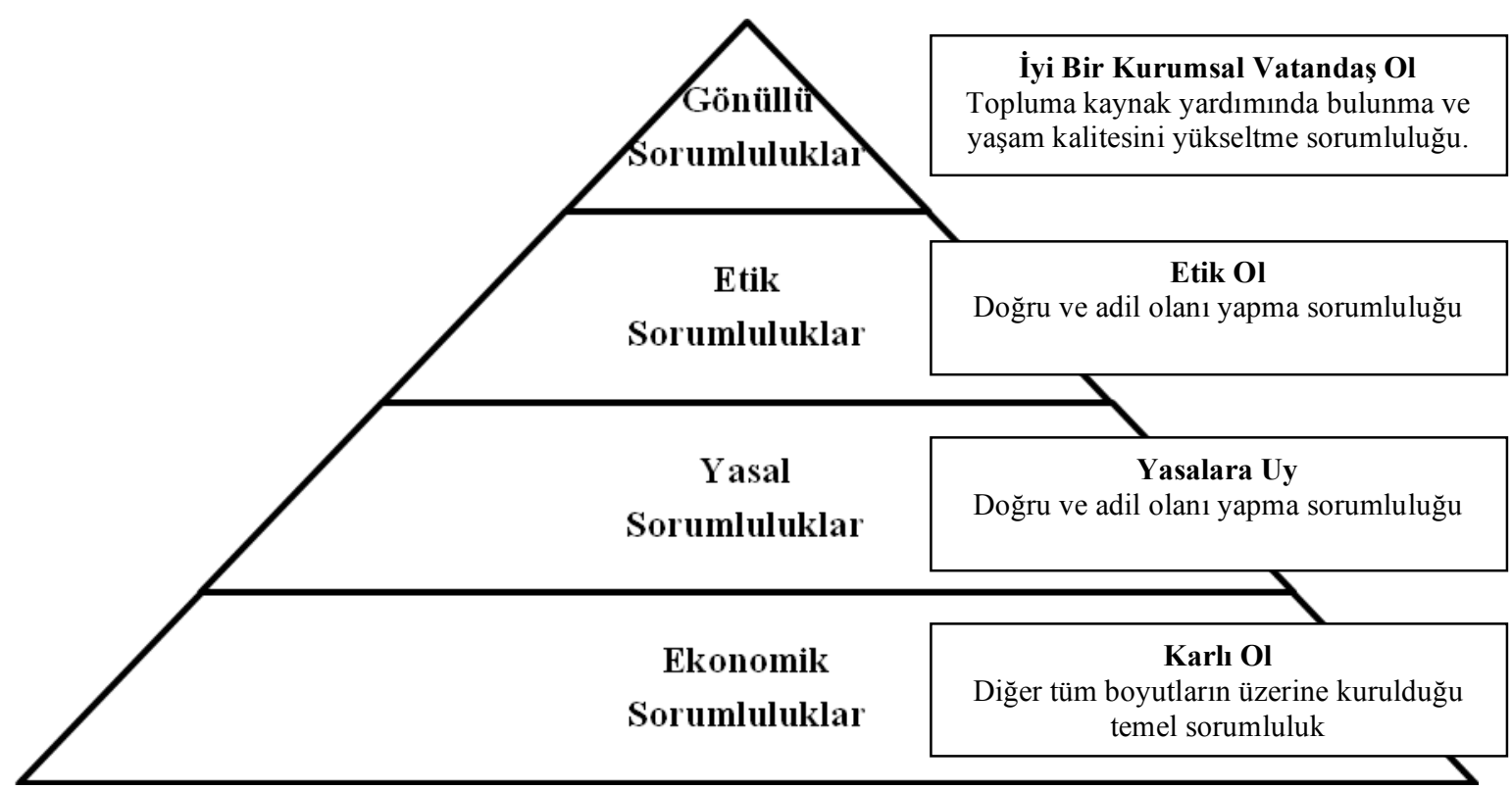

Kaynak: Archie B. Carroll (1991). The Pyramid of Corporate Social Responsibility: Toward the Moral Management of Organizational Stakeholders. Business Horizons, 34(4), s. 42.

Argüden (2007:37)'e göre kurumsal sosyal sorumluluk, Caroll (1991)'un hiyerarşisindeki sorumlulukların son ikisini, ancak dolaylı olarak da hepsini kapsamaktadır. Çünkü, toplumun beklentilerine uyumlu olan, onun sorunlarına ilgi gösteren işletmelerin toplumda oluşturduğu mutluluk, daha mutlu çalışanlara, daha mutlu müşterilere ve dolayısıyla daha mutlu hissedarlara sahip olmaları sonucunu ortaya çıkartmaktadır. Bu çerçevede kurumsal sosyal sorumluluk, işletmelerin daha iyi bir toplum ve daha iyi bir çevre için gönüllü olarak katkıda bulunması anlamina gelmektedir.

Tanımlar çerçevesinde kurumsal sosyal sorumluluk kavramının, işletmelerin çalışanları için sağlık ve güvenlik düzenlemelerinden, çevrenin korunmasına ve birlikte yönetime kadar çok çeşitli alanları kapsadığı görülmektedir. Dolayısıyla kurumsal sosyal sorumluluğun oldukça geniş bir kapsamı olduğunu söylemek mümkündür. Sürdürülebilir Kalkınma Dünya İş Konseyi, sosyal sorumluluklar ile yasaların üzerinde etkinlik sağlanabilecek alanları şöyle sıralamıştır (Ersöz, 2007:22);

- Kurumsal yönetim ve ahlak,

- Sağlık ve güvenlik,

- Çevreye ait sorumluluklar,

- Temel çalışma standartlarını içeren insan hakları, 
- İnsan kaynakları yönetimi,

- Toplumsal katılım, kalkınma ve yatırım,

- Yerel halka saygi ve kaynaşma,

- Kurumsal hayırseverlik ve çalışanların gönüllülüğg̈,

- Müşteri tatmini ve adil rekabet prensiplerine bağlilık,

- Rüşvet ve yozlaşmaya karşı önlemler,

- Hesap verebilirlik, şeffaflık ve performans raporlama,

- Ulusal ve uluslararası tedarikçilerle iliş̧iler.

Kurumsal sosyal sorumluluğun birçok yazar tarafından farklı şekilde tanımlanmasına rağmen, bu tanımların çoğunda ortak olan dört unsurdan söz etmek mümkündür (Sönmez, 2004:479).

- İşletmelerin kâr elde etmek için mal ve hizmet üretmelerinin ötesinde sorumlulukları vardir.

- İşletmelerin ortaya çıkmasına katkıda bulundukları sosyal sorunların çözümüne katkıda bulunması gerekmektedir.

- İşletmeler sadece hissedarlara karşı değil, sosyal paydaşlar olan çevreye karşı da sorumludurlar.

- İşletmeler ekonomik değerlere odaklanmalı, daha geniş anlamda insani değerlere hizmet etmelidir.

Bununla birlikte tanımlarda en fazla yer alan unsurlardan biri de kurumsal sosyal sorumluluğun gönüllülük niteliğidir. Bu çerçevede kurumsal sosyal sorumluluk yasal düzenlemelerin ötesinde gönüllü olarak gerçekleştirilen faaliyetleri kapsamaktadır. Araştırmacıların da kurumsal sosyal sorumluluk faaliyetlerini çevre, pozitif ayrımcılık programları, eşit istihdam politikaları, toplumsal katılım faaliyetleri, ürün güvenliği ve enerji politikaları gibi birçok alanda incelediği görülmektedir (Roberts, 1992:596). Dolayısıyla kurumsal sosyal sorumluluk işletmelerin sadece hissedarlarına karşı değil, aynı zamanda çevreye ve topluma karşı sorumluluk bilinci içerisinde gönüllü faaliyetler yerine getirmesi anlamına gelmektedir.

\section{KURUMSAL SOSYAL SORUMLULUK TEORIILERİ}

İşletmelerin sosyal sorumluluklarına ilişkin araştırmalar daha önce de belirtildiği gibi 1950’lerin ortalarından sonra hız kazanmıştır. O günlerden günümüze gelene kadar kurumsal sosyal sorumluluk alanında büyük bir gelişim olduğu ve kavrama ilişkin terminolojide de bir değişim olduğu söylenebilir. Bu çerçevede günümüzde kurumsal sosyal sorumluluğa ilişkin farklı teorilerden ve yaklaşımlardan bahsetmek mümkündür. 
Kurumsal sosyal sorumluluk teorileri ve yaklaşımları genel olarak toplumsal gerçekliğin ekonomik, politik, sosyal ve etik boyutlarından birine odaklanmaktadır. Dolayısıyla kurumsal sosyal sorumluluk teorilerine ilişkin uygun bir sınıflama yapılırken bu dört boyutun dikkate alınması gerekmektedir. Bu varsayımın arkasındaki mantık, belirtilen dört boyutun bütün sosyal sistemlerde görülebileceğidir. Bu varsayımdan hareketle de kurumsal sosyal sorumluluk teorileri dört başlik altında toplanabilir (Garriga ve Mele, 2004:52-53).

1. Araçsal Teoriler: Bu teoriler kapsamında değer ve zenginliğin ortaya çıkartılmasında işletmelerin bir araç olduğu varsayılmakta ve bu işletmenin temel sosyal sorumluluğu olarak kabul edilmektedir. Bu bakış açısından işletme ve toplum arasındaki etkileşim yalnızca ekonomik yönü ile değerlendirilmektedir. Dolayısıyla herhangi bir sosyal faaliyet yalnızca değer ve zenginlik ortaya çıkartması durumunda kabul edilmektedir. Araçsal teoriler kapsamında kurumsal sosyal sorumluluk kârlılığın temel aracı durumundadir.

2. Politik Teoriler: Bu teoriler, işletmenin toplumsal ilişkilerindeki sosyal gücüne ve bu güçle ilişkili politik alandaki sorumluluklarına odaklanmaktadır. Bu durum işletmenin sosyal görev ve haklarını kabul etmesi veya toplumsal işbirliklerine katılımı sonucunu doğurur.

3. Bütünleștirici Teoriler: Bu teorilere göre işletmenin, toplumsal talepler ile faaliyetlerini bütünleştirmesi gerekmektedir. İşletmenin sürekliliği ve gelişimi ve hatta varlığ içinde bulunduğu toplumla bütünleşebilmesine bağlıdır.

4. Etik Teoriler: $\mathrm{Bu}$ teoriler, işletme ve toplum arasındaki ilişkide etik değerlere odaklanmaktadır. Böylece, kurumsal sosyal sorumluluk etik bir bakış açısı kazanmış olmakta ve bunun bir sonucu olarak işletmeler sosyal sorumluluklarını diğer nedenlerin ötesinde etik bir yükümlülük olarak görmektedir.

\section{3. İŞLETMELERI KURUMSAL SOSYAL SORUMLULUK FAALIYYETLERINE YÖNELTEN NEDENLER}

İşletmelerin topluma karşı da görevlerinin bulunduğu düşüncesi günümüzde güçlü bir şekilde destek görmektedir. Bu çerçevede işletmeler yalnızca ekonomik faaliyetleri sonucunda elde ettikleri başarılar ile değil, ayrıca sosyal sorumluluk faaliyetleriyle de değerlendirilmektedir (Carroll, 1991:39; Lantos, 2001:596).

$\mathrm{Bu}$ çerçevede işletmeleri, faaliyetlerinde kendi amaçlarını yerine getirirken toplumu da düşünerek hareket etmeye yönelten, diğer bir ifadeyle kurumsal sosyal sorumluluk faaliyetlerine yönelten farklı nedenler bulunduğu söylenebilir. Bu nedenlerden ötürü günümüz işletmeleri kurumsal sosyal sorumluluk kavramına geçmiş hiçbir dönemde olmadığ kadar önem vermeye başlamıştır. Bunda, günümüz işletmelerinin kurumsal sosyal sorumluluk faaliyetleri sayesinde kendileri için de ciddi kazanımlar elde edeceklerini görmüşs olmalarının 
büyük etkisi bulunmaktadır. Örneğin, kurumsal sosyal sorumluluk faaliyetleri aracıllğıyla elde edilen kurum imajının ya da kurumsal itibarın işletme için hayati öneme sahip olduğu bilinen bir gerçektir (Aktan ve Börü, 2007:19). Bazı ünlü markaların çalışanlarına kötü çalışma şartları sağlaması, çocuk işçi çalıştırması gibi nedenlerle medyada uzun süre yer alması, bu markaların itibarlarını da olumsuz yönde etkilemiştir. Bu olumsuzlukların giderilmesi için kurumsal sosyal sorumluluklara ağırlık verilmiş, bu konuyla ilgili olarak üst düzey kadro oluşturma yoluna gidilmiştir. Günümüzde şirketler yılsonunda bilançoları yanında kurumsal sosyal sorumluluk raporlarını da yayınlamaya başlamıştır (Torlak, 2013b:84). Bununla birlikte kurumsal sosyal sorumluluk faaliyetleri, işletmenin marka değerini ve dolayısıyla piyasa değerini arttırmaktadır. Günümüzde müşteriler bir ürünü sadece kalitesi ve maddi değeri ile değil, bu ürünü üreten işletmenin sosyal sorumluluk faaliyetleri ile birlikte değerlendirerek de tercih etmektedir (Aktan ve Börü, 2007:27).

McWilliams ve Siegel (2001:119) işletmelerin kurumsal sosyal sorumluluk faaliyetlerine yönelmesinin iki temel kaynağı bulunduğunu belirtmektedir. Bu kaynakların ilki müşteri talepleri, ikincisi ise yatırımcılar, çalışanlar ve toplum gibi diğer paydaşların talepleridir. Dolayısıyla ilk kaynak çerçevesinde işletmeler ürün ve hizmetlerini satın alan müşteriler, diğer bir ifadeyle ekonomik nedenlerle kurumsal sosyal sorumluluk faaliyetlerine odaklanmaktadır. İkinci kaynak çerçevesinde ise, işletmeleri kurumsal sosyal sorumluluk faaliyetlerine yönelten neden sosyal faktörler olarak görülmektedir.

Campbell (2007) de benzer şekilde işletmelerin sosyal sorumluluk faaliyetlerine yönelme nedenini ekonomik ve kurumsal faktörler olarak ikiye ayırmaktadır. Ekonomik faktörler, kurumsal davranış üzerinde belirleyici olan faktörlerdir. Diğer bir ifadeyle kurumsal davranışlar üzerinde ekonomik yapı ve koşullar ile ekonomik konjonktür etkili olmaktadır. Kurumsal faktörler ise tümüyle ekonomik koşullardan bağımsız olarak ortaya çıkmamakta olup, sosyal bakımdan sorumlu davranış değişikliği, kurumsal değişiklikten ve bu kurumların sınırlayıcı ve teşvik edici davranış farklılığından meydana gelmektedir (Ersöz, 2007:45).

Genel olarak, kurumsal sosyal sorumluluk konusuna önem veren işletmelerin elde edeceği kazanımlar aşağıdaki şekilde sıralanabilir: (Özüpek, 2008'den akt. Becan, 2011:19):

1. Daha iyi bir sosyal çevre oluşturmak hem topluma hem de işletmeye fayda sağlamaktadır. Toplum açısından duruma bakıldığında, sosyal sorumlulukların yerine getirilmesiyle daha iyi bir çevre ve iş fırsatları oluşturulmuş olacaktır. İşletme açısından duruma bakıldığında ise daha fazla iş gücü kaynağı bulacak ve ürettiği ürün veya hizmetlerine daha kolay müşteri çekecektir. 
2. Sosyal hareketlere işletmenin gönüllü olarak katılması bu konuda hükümetin daha sıkı düzenleme ve müdahalesine yol açacaktır. Böylece işletmeler daha fazla esnekliğe ve bağımsızlığa kavuşacaktır.

3. İşletmeler modern toplumla bağımlı sistemlerdir ve işletme ile toplum arasındaki karşılıklı bu bağımlılık, kurumun faaliyetini önemli şekilde etkilemektedir. İşletmenin çevresinde bulunan çıkar gruplarının istekleri tatmin edildiği ölçüde pazardaki varlığı da riske girmez. İşletmenin sosyal katılımı desteklemesinde kamuoyunun görüşü önemli bir rol oynamaktadır. Çünkü verimlilik amaçları hayatın kalitesiyle bir arada beklenmektedir.

4. İşletmenin yenilikçi kapasitesi toplumsal sorunlara uygulanabilirse, geleneksel anlamda işletmeye maliyetli gibi gözüken bir takım çalışmalar işletmeye katkı sağlayabilir. Bazen toplumsal konulara tepki göstermek yerine önlem almak daha tutarlı ve daha az maliyetli olmaktadır. Bu nedenle işletmeler, sosyal sorunlar baş göstermeden önce tedbirlerini alacak olursa, hem tepkiler azalacak hem de önlem almanın maliyeti azalacaktır.

5. Sosyal hareket, destekleyen bir halk imajı oluşturmaktadır. Böyle bir imaj oluşturan işletmeler müşterileri, çalışanları ve yatırımcıları da çekebilmektedir.

6. İşletmeler güçlü, beşeri ve maddi kaynaklara sahiptir, özellikle toplumun bazı sorunlarını çözmek için kendi kaynaklarını kullanan işletmeler toplumda prestij sağlamaktadır.

7. Her yönüyle saygın ilişkileri hedefleyen işletme; iyileştirilmiş bir çevrede başarılı olabilmekte ve kazanç sağlayabilmektedir.

8. Sosyal sorumluluklarını yerine getiren işletmeler etik yükümlülüklerini tanımlayarak kamuoyunun değişen ihtiyaçlarını, beklentilerini ve işletmelerin yol açtığı sosyal sorunları çözmektedir.

$\mathrm{Bu}$ kazanımlara ek olarak kurumsal sosyal sorumluluk faaliyetlerine önem veren işletmelerin; marka değerleri ve dolayısıyla piyasa değerleri artmakta, daha nitelikli insan kaynaklarını cezbetme, motive etme ve elde tutma imkanı ortaya çıkmakta, kurumsal öğrenme ve yenişim (inovasyon) potansiyeli artmakta, özellikle bu konularda hassas yatırımcılara ulaşma imkanı oluştuğundan, hisse değeri artarken, borçlanma maliyetleri azalmakta, yeni pazarlara girme ve müşteri sadakati sağlamada önemli avantajlar elde edilmekte, verimlilik ve kalite artmakta, risk yönetimi daha etkin hale gelmekte ve kamuoyu ile kural koyucuların şirketin görüşlerine önem vermesi sağlanmaktadır (Argüden, 2007:40).

Sonuç olarak, finansal performansı güçlü olan işletmelerin, zayıf olan işletmelere göre muhtemelen daha fazla kurumsal sosyal sorumluluk davranışı göstereceği düşünülebilir. Çünkü, daha kârlı işletmeler, yöneticilerinin tercih etmesi halinde, zayıf yapıdaki işletmelere göre kurumsal sosyal sorumluluk faaliyetleri için daha fazla kaynağa sahip olan işletmeler durumundadır. Buna karşılık zayıf olan işletmeler ise minimum sosyal sorumluluk davranışlarını yerine getirebilmekten dahi yoksun kalmaktadır. Elbette böyle bir işletmenin 
yöneticisi, işletmenin finansal koşullarını iyileştirmek için sosyal sorumluluk projelerine kaynak ayırmaktan kaçınabilir (Ersöz, 2007:46). Campbell (2007) tarafından gerçekleştirilen çalışma bu olguyu destekler şekilde, finansal olarak güçlü, sağlıklı ekonomik çevrede faaliyette bulunan, yoğun rekabet içerisinde olan işletmelerin sosyal sorumluluk faaliyetlerine daha fazla yöneldiklerini göstermektedir.

\section{4. İŞLETMELERİN SOSYAL SORUMLULUK ALANLARI}

Klasik yaklaşım çerçevesinde ekonomik ve yasal sorumlulukların işletmelerin sosyal sorumlulukları açısından yeterli olduğu savunulmaktadır. Fakat günümüzde, işin ve iş yapma biçiminin değişmesi ve iş dünyasının tüketim ve tüketici bağlamında toplumla etkileşim içerisinde olmasıyla birlikte işletmelerin sosyal sorumluluk anlayışlarının daha kapsamlı olarak düşünülmesinin gerekliliği ortaya çıkmaktadır. Bu doğrultuda kâr elde etmek ve işletmenin sürdürülebilirliğini sağlamanın yanında topluma hizmet etmenin amaç edinilmesi işletme için sosyal sorumluluğun ötesinde ahlaki bir eylem olarak görülmektedir (Torlak, 2013a:33).

İşletmelerin sosyal sorumluluk alanı, toplumun refah ve mutluluğunun arttırılmasını amaçlayan tüm işletme faaliyetlerini kapsamaktadır. Dolayısıyla sorumluluk alanı denildiğinde hissedarlara, çalışanlara, müşterilere, çevreye, genel olarak topluma karşı sorumluluklardan bahsedilmektedir.

\subsection{Hissedarlara Karşı Sorumluluklar}

Sosyal sorumluluk kapsamına giren ilk konu, işletmenin ve onun yöneticilerinin hissedarlara veya sermaye sahiplerine karşı olan yükümlülükleridir. İşletmenin en önemli kaynağ1 sermayesidir. Sermaye sağlayan hissedarlar bunun karşılığında belirli bir kâr temin etmek isteyeceklerdir (Halıcı, 2001:16). Hissedarlar, temel olarak yatırım yaptıkları işletmenin kâr sağlayarak kendilerine finansal getiride bulunmasını istemektedir. Ayrıca hisse değerlerinin artması da beklenmektedir. İşletmeler düşük bir maliyetle finansman sağlamaya çalışmakta, karşılık olarak kâr payı dağıtarak hissedarların faaliyetlerini ve politikalarını desteklemesini beklemektedir. İşletmelerin kararları yatırımcısını doğrudan etkilemektedir. İşletmelerin, yatırımcılarına saygı duymaları, onların haklarını korumaları gerekmektedir. İşletme gelir sağlayamadığı takdirde yatırımcı desteğini çekecek, bu da işletmenin sermaye kaybına neden olacaktır (Torlak, 2013a:40).

$\mathrm{Bu}$ çerçevede, işletmelerin hissedarlarına karşı temel sorumlulukları olarak onların çıkarlarını maksimize etmek gösterilebilir. Hissedarlar, maksimum kâr elde etmeye uğraşmanın 
yanı sıra şirketin sürekliliğinin sağlanması, topluma hizmet, kaliteli mal ve hizmet üretilmesi, istihdamın sürekli kılınması, yeni iş alanları ve iyi bir ücret politikasının uygulanması gibi beklentiler içine girebilir (Çelik, 2007:68). Hissedarların işletmeden en önemli beklentisi ise, işletme üzerindeki sahiplik haklarının korunmasıdır. Hissedarların, hisselerini satma, genel toplantılarda oy kullanma, işletme ile ilgili bilgi alma, işletmenin yasalara uymayan uygulamaları ve topluma zarar veren faaliyetleri için işletme yöneticilerini dava etme gibi hakları bulunmaktadır (Torlak, 2013a:40).

Aktan ve Vural (2007:15), işletmelerin hissedarlarına ve yatırımcılarına karşı sorumluluklarını aşağıdaki şekilde özetlemektedir.

- Hissedarların çıkarlarını korumak ve gözetmek,

- Hissedarlarla ve yatırımcılarla ilgili bilgilerden yalnızca yasal hükümler ve rekabete dayalı zorunluluklara konu olanları açıklamak,

- Hissedarların yatırımcıların taleplerine, önerilerine, şikayet ve resmi tekliflerine uymak.

Sosyal sorumluluklarını yerine getiren işletmeler daha fazla kaynak sağlayarak yatırımlarını arttırabilmektedir. Yatırımların büyümesi kârlılığı olumlu etkileyerek şirket değerini yükseltmektedir. Sonuç olarak hissedarlar sosyal sorumluluk faaliyetleri ile dolaylı yoldan finansal getiri elde etmektedir (Akdemir, 2008:59-60).

\section{2. Çalışanlara Karşı Sorumluluklar}

İşletmelerin en temel paydaşı çalışanlarıdır. Çalışanlar, işletmenin müşterileri ile ilişkilerinde bir temsilci görevi görmektedir. Ayrıca çalışanlar işletmedeki mal ve hizmetlerin kalitesini belirleyen, kurum imajında oldukça önemli bir yere sahip olan, müşteri tatmininin önemli bir unsuru olan ve işletmenin iç müşterileri olarak isimlendirilen gruptur.

Bir işletme amaçlarına çalışanları aracılığıyla ulaşmaktadır. Dolayısıyla, kurumun en temel kaynaklarından biri olan çalışanlar, sosyal sorumluluk uygulamalarının ilk etapta göz önünde bulundurulması gereken boyutudur. Çalışanların verimli olması amaçlanıyorsa onların motivasyonu dikkate alınmalıdır.

Çalışanlar sosyal sorumluluk sürecinde hem kararlara katılarak hem de kararların uygulanmasından etkilenen taraflar olarak yer almaktadır. Çalışanların çalışma saatleri, ücretleri ve çalışma koşullarıyla ilgili düzenlemelerin asgari boyutu yasalar yoluyla düzenlenmekle birlikte toplu sözleşme ve sosyal diyalog süreçleriyle iyileştirilmektedir. 
Çalışanların işletmenin sorumlu olduğu diğer gruplardan daha farklı rolleri bulunmaktadır. İşletme çalışanı bazen bir temsilci, müşteri ya da toplumun bir üyesi olarak işletmenin ekosistemi içerisinde yer alabilmektedir (Torlak, 2013a:39).

Çalışanlarla ilgili olarak, istihdam imkanları ve çalışma koşullarının iyileştirilmesine yönelik Uluslararası Çalışma Örgütünün (ILO) çeşitli düzenlemeleri mevcuttur. ILO yaptırımlarına göre, küresel, ulusal veya yerel çevrede faaliyet gösteren her işletme yönetimi, aşağıda sıralanan koşullara uymak zorundadır (Çelik, 2007:68):

- Çocukların çalışma, yaş ve saatleri: 15 yaşın altında çoçuk işgören çalıştırılamaz. Bu konudaki kısmi izinler, özel düzenlemelerle sınırlandırılmıştır. $\mathrm{Bu}$ yaşın üzerindeki çocuk çalışan eğer okula devam ediyorsa, iş için harcayacağ 1 toplam zaman günde 10 saati (iş, okul ve ulaşım dahil) geçemez.

- Zorla çalıştırılan kişiler: İşletme zorla insan çalıştıramaz veya çalışanlarının kimliklerini ya da belli bir depoziti şirkete bırakmalarını isteyemez.

- Sendika kurma ve toplu pazarlık hakkl: Çalışanlar sendika kurma, sendikaya katılma ve toplu pazarlık hakkına sahiptirler.

- Çalışma saatleri: İnsan kaynakları haftada 48 saatten fazla çalıştırılamaz. Kısa dönemli olağanüstü iş koşulları hariç fazla mesailer haftalık 12 saati geçemez.

- Maaş ve ücretler: Ücretler en azından ülkenin asgari ücret seviyesinde ve insan kaynaklarının temel ihtiyaçlarını karşılamaya yetecek düzeyde olmalıdır.

- Sağllk ve güvenlik: Şirket sağlıklı bir çalışma ortamı sunmak, kaza ve yaralanmaları önleyici tedbirleri almak, sağlık ve güvenlik eğitimini vermek, temiz sağl1k merkezleri ve içilebilir su sağlamak zorundadır. Doğum ve süt izni gibi konularda yasal düzenlemelere uymak zorunludur.

- Ayırımcılık ve disiplin uygulamaları: İnsan kaynakları cinsiyet, etnik köken vb. nedenlerden dolayı farklı muameleye tabi tutulamaz ve çalışanlara dayak, küfür vb. fiziksel veya psikolojik baskı uygulanamaz.

- Engelli ve eski hükümlü çalıştırma: Büyük ölçekli işletmeler başta olmak üzere, işletmelerin belirli bir oranda engelli ve eski hükümlü çalıştırmak zorunlulukları vardır.

Bununla birlikte çalışanlara karşı sorumluluklar yalnızca işletme içi sorumluluklar olarak düşünülmemelidir. İşletmelerin öncelikle işsizliği azaltma yönünde sorumlulukları bulunmaktadır. Ayrıca işletmelerin insan kaynaklarını işe alırken de uyması gereken bazı sorumlulukları vardır. Bu çerçevede yaş, cinsiyet, ırk, din, dil vb. kişisel özellikler açısından farklılık gözetmeme bir işletmenin sosyal sorumluluk alanı içerisinde düşünülebilir.

\subsection{Müşterilere Karşı Sorumluluklar}

İşletmelerin en çok üzerinde durduğu sosyal sorumluluk alanlarının başında, müşterilere yönelik olan sosyal sorumlulukları gelmektedir. Bunun en önemli nedeni olarak, tüm sektörlerdeki işletmelerin pazardaki varlığını sürdürebilmesinin ve amacına ulaşabilmesinin 
müşterilerden geçmesidir. Dolayısıyla, kaliteli ürün ve hizmetlerin sunulmasının yanı sıra, müşterilerin her türlü ihtiyaçlarını, beklentilerini ve isteklerini öngörmek ve buna göre davranmak, müşterilere karşı sorumluluğunun bir gereği olarak önemli bir rol oynamaktadır (Becan, 2011:20-21).

İşletmelerin çıkarlarını koruyabilmesi ve amaçlarına ulaşabilmesi için, toplumsal amaçlara katkıda bulunması gerekmektedir. İşletme çıkarları ile toplumda güç dengelerini oluşturan grupların çıkarlarının dengelenmesi, işletmenin amaçlarına daha kolay ulaşabilmesine katkı sağlamaktadır. Bu çerçevede müşterilerin de tatmininin sağlanması ve bu gaye için de kaliteli, ucuz üretim ve satış sonrası hizmetlere önem verilmesi gerekir (İşseveroğlu, 2001:62).

Müşterilerin işletmeler karşısındaki gücü gün geçtikçe artmakta ve bunun farkında olan işletmeler de etik davranışlar sergileyerek ve müşteri memnuniyetine önem vererek rekabet avantajı sağlamaya çalışmaktadır. Günümüzde müşteriler daha bilinçli olarak ürün ve hizmetleri tercih etmektedir. Ayrıca tercihlerinde işletmenin çocuk işçi çalıştırıp çalıştırmadığ çevreye duyarlı üretim yapılıp yapılmadığı gibi faktörler de etkili olmaktadır (Sönmez, 2014:19).

İşletmelerin hem müşteriyi koruyan davranışlar göstermesi, hem de istismarcı kişi ve gruplarla mücadele etmesi önemli bir sosyal sorumluluğudur. Müşteri, bir mal veya hizmeti ihtiyacı için almaktadır. Bu açıdan işletmelerin, müşterilerin ihtiyaçlarını giderecek özelliklere sahip mal ve hizmet üretmeleri gereklidir. Üretilen ürünlerin hangi maddelerden yapıldığ 1 , herhangi bir tehlike taşıyıp taşımadığı ve nasıl kullanılacağı hakkında kullanma kılavuzları hazırlanıp ambalajların içine yerleştirilmelidir. Diğer bir husus ise, bu mal veya hizmetin, kalite kontrolünden geçirildikten sonra piyasaya sürülmesidir. Şirketin müşteriye gösterdiği sorumluluk maliyetli olabilir, ancak pazar payındaki artışlar bu çabalara destek olabilecektir (Çelik, 2007:67). Diğer taraftan günümüz işletmelerinin sağlık, eğitim, çevre, kültür-sanat vb konularda gerçekleştirdikleri sosyal sorumluluk çalışmaları ile de müşterilerin ihtiyaçlarına hitap ettikleri görülmektedir (Vural ve Coşkun, 2011:75).

\section{4. Çevreye Karşı Sorumluluklar}

İşletmelerin sosyal sorumlulukları kapsamında özel bir yeri olan çevrecilik anlayışı 1990’l1 yıllardan itibaren gittikçe artan bir eğilim göstermektedir. Gelişmiş Avrupa ülkelerinde faaliyet gösteren birçok işletme, halkla ilişkiler fonksiyonlarında çevre dostu imajı oluşturmak yönünde faaliyetlerde bulunmaktadır. Bu işletmelerin müşterilere sundukları malların ekolojik 
yapıya uygun hale getirilmesi yanında, çevresel standartlar oluşturma yolunda da bir takım çalışmalar içinde oldukları gözlemlenmektedir. Çevreci gruplar ve işletmeler arasında artan çevre birlikteliği uygulamaları, gelişmeler olumlu ise işbirliğine, olumsuz ise çatışmaya dönüşme eğilimindedir. İşletmelerin örgütsel amaçları saptanırken çevreci örgütlerle işbirliğine gidilmesi başarılı bir iletişim ve halkla ilişkiler eylemi olarak algılanmaktadır. Çevreci örgütlerin ekolojik yapıyı koruma yolunda gösterdikleri gayretler her geçen gün daha da gelişme göstermektedir (Çelik, 2007:74).

Günümüzde, işletmeler için faaliyette bulundukları ülkelerdeki yasa, yönetmelik ve idari uygulamalar çerçevesinde çevreyi koruma ve genel olarak faaliyetlerini sürdürülebilir kalkınma amacına katkıda bulunacak şekilde gerçekleştirmek bir zorunluluk durumundadır (Aktan ve Vural, 2007:9). Bu çerçevede işletmelerin, hem kaynakların etkin kullanımı hem de çevreye zarar vermeyecek ya da bu zararı minimize edecek teknolojileri seçip kullanması daha da önemli hale gelmektedir. Ekonomik kararlar için, özel maliyetler ve özel faydalar dikkate alınırken aynı zamanda, dışsal maliyet ve dışsal faydalar da ihmal edilmemelidir (İşseveroğlu, 2001:64).

İşletmeler, yaşadığımız çevreye hava, su, toprak ve gürültü kirliliği, iklim değişikliği, bazı bitki ve hayvan türlerinin yok olması gibi doğal ve insan yaşamını tehdit eden ve bazı durumlarda geri dönülmesi mümkün olmayan zararlar vermektedir. İşletmelerin yaşadığımız çevrenin dengesini bozmaya başlamasının ve bunun insan hayatı üzerindeki etkilerinin farkına varılmasıyla birlikte çevreye zarar veren işletmelerin hem yasalar yoluyla hem de toplumsal duyarlılığın geliştirilmesi yoluyla faaliyetlerinin sınırlandırılmasına veya yasaklanması yoluna gidilebilmektedir (Torlak, 2013a:42).

Günümüzde işletmelerden, bir taraftan ürün ve hizmet üretirken, diğer taraftan toplum içerisinde sahip olduğu sosyal konum itibariyle önceden tedbir alıp çevreyi kirletmemesi ve buna yönelik çalışmaları desteklemesi beklenmektedir. Genel olarak, üretim sürecinde doğaya zarar vermemek, doğaya zarar verebilecek tüm ihtimallere karşı önlemler almak, doğal kaynakları verimli kullanmak gibi tüm davranışlar işletmelerin çevreye karşı sosyal sorumluluklarını içermektedir. Böyle bir yaklaşım tarzı da işletmeleri, ekonomik bir birim olma anlayışından sosyal bir varlık kimliğine yöneltmektedir (Becan, 2011:20).

\section{SONUÇ}

Küreselleşme olgusu ile birlikte işletmeler, ekonomik birimlerden sosyal birimlere dönüşmektedir. Sosyal birim olarak işletmelerin içinde bulunduğu topluma karşı ekonomik 
sorumluluklarının yanında sosyal sorumluluklarının da bulunduğu kabul edilmektedir. $\mathrm{Bu}$ çerçevede son yıllarda iş dünyası için kurumsal sosyal sorumluluk, yeni değil fakat çok daha önemli bir kavram olarak ortaya çıkmaktadır.

Kurumsal sosyal sorumluluk, işletmelerin sadece hissedarlarına karşı değil, aynı zamanda çalışanlarına, müşterilere, devlete, tedarikçilere, çevreye ve topluma karşı sorumluluk bilinci içerisinde gönüllü faaliyetler yerine getirmesini ifade etmekte ve işletmeler için itibar, tanınırlık ve tercih edilirlik anlamına gelmektedir. Dolayısıyla, yoğun rekabetin yaşandığı günümüz ekonomilerinde işletmelerin kurumsal sosyal sorumluluk faaliyetlerine önem vermesi ve bu faaliyetler için fazladan çaba harcaması bir zorunluluk durumundadır.

Sosyal fayda amaciyla gerçekleştirilen faaliyetler, işletmeler için bir maliyet unsuru olarak değil, hem işletmelere hem de topluma kazanımlar sağlayan ve bu çerçevede gelişimi destekleyen faaliyetler olarak değerlendirilmelidir. $\mathrm{Bu}$ çerçevede, kurumsal sosyal sorumluluklar kapsamında yerine getirilen faaliyetler sonucunda işletmeler, piyasa değerinin artması, insan kaynaklarının motivasyonunun ve bağlılığının artması, yeni ve farklı pazarlara girme imkânının artması, verimlilik ve kalitenin artması gibi kazanımlar elde etmektedir. Diğer taraftan, hissedarların çıkarlarının korunması ve gözetilmesi, topluma kaliteli ürün ve hizmetlerin sunulması, doğaya zarar verebilecek faaliyetlere karşı önlemler alınması ve doğal kaynakların verimli kullanılması gibi toplumsal faydalar da sağlanmaktadır. Dolayısıyla sosyal sorumluluk anlayışı işletmenin tüm süreçlerine yayılmalı, işletme içerisinde sosyal sorumluluk anlayışını destekleyen bir kültür oluşturulmalı ve bunun sürekliliğinin sağlanması amacıyla gerekli politikalar oluşturulmalıdır. 


\section{KAYNAKÇA}

Adeyeye, A. (2012). Corporate Social Responsibility of Multinational Corporations in Developing Countries: Perspectives on Anti-Corruption. Cambridge, New York: Cambridge University Press.

Akdemir, G. (2008). Tüketicilerin Kurumsal Sosyal Sorumluluk Uygulamaları Yürüten İşletmelere Karşı Tutumlarl ve GSM Sektörü Üzerine Bir Araştırma. Yayımlanmamış Yüksek Lisans Tezi. İstanbul Üniversitesi Sosyal Bilimler Enstitüsü. İstanbul.

Aktan, C. C. ve Börü, D. (2007). "Kurumsal Sosyal Sorumluluk". (Ed.: C. C. Aktan), Kurumsal Sosyal Sorumluluk: İşletmeler ve Sosyal Sorumluluk (s. 11-36). İstanbul: İGİAD Yayınları.

Aktan, C. C. ve Vural, İ. Y. (2007). "Kurumsal Sosyal Sorumluluk: Uluslararası Kuruluşlar ve Hükümet-Dış1 Organizasyonlar Tarafından Sürdürülen Başlıca Girişimler”. Çimento İşveren Dergisi, 21(3), s. 4-21.

Argüden, Yilmaz (2007). "Kurumsal Sosyal Sorumluluk”. (Ed.: C. C. Aktan), Kurumsal Sosyal Sorumluluk: İsletmeler ve Sosyal Sorumluluk (s. 37-44). İstanbul: İGİAD Yayınları.

Becan, C. (2011). "Kurumsal Sosyal Sorumluluk Kavramının Paydaş Teorisi ve İletişim Yaklaşımı Açısından Değerlendirilmesi: Bankaların Basın Bültenlerine Yönelik Bir İçerik Analizi”. Selçuk Üniversitesi İletişim Fakültesi Dergisi, 7(1), s. 16-35.

Campbell, J. L. (2007). "Why Would Corporations Behave in Socially Responsible Ways? An Institutional Theory of Corporate Social Responsibility”. Academy of Management Review, 32(3), s. 946-967.

Carroll, A. B. (1991). "The Pyramid of Corporate Social Responsibility: Toward the Moral Management of Organizational Stakeholders". Business Horizons, 34(4), s. 39-48.

Commission of the European Communities (2001). Green Paper: Promoting A European Framework for Corporate Social Responsibility. Brussels: COM/366 Final.

Crowther, D. ve Aras, G. (2008). Corporate Social Responsibility: Principles, Stakeholders and Sustainability (Vol. Part 1): Bookboon.

Çelik, A. (2007). “Şirketlerin Sosyal Sorumlulukları”. (Ed.: C. C. Aktan), Kurumsal Sosyal Sorumluluk: İşletmeler ve Sosyal Sorumluluk (s. 61-84). İstanbul: İGİAD Yayınları.

Davis, K. (1960). “Can Business Afford to Ignore Social Responsibilities?”. California Management Review, 2(3), s. $70-76$.

Ersöz, H. Y. (2007). Türkiye'de Kurumsal Sosyal Sorumluluk Anlayışının Gelişiminde Meslek ve Sivil Toplum Kuruluşları. İstanbul Ticaret Odası Yayınları, Yayın No: 2007-36, İstanbul.

Garriga, E. ve Mele, D. (2004). “Corporate Social Responsibility Theories: Mapping the Territory”. Journal of Business Ethics, 53(1/2), s. 51-71.

Halıcı, A. (2001). "İ̧sletmelerde Sosyal Sorumluluk Stratejileri: Çanakkale İlinde Bir Araştırma”. Yönetim ve Ekonomi, 7(1), s. 11-26.

Hennigfeld, J., Pohl, M. ve Tolhurst, N. (2006). The ICCA Handbook on Corporate Social Responsibility. West Sussex, England.: John Wiley \& Sons Ltd.

İşseveroğlu, G. (2001). “İşletmelerde Sosyal Sorumluluk ve Etik”. Yönetim ve Ekonomi, 8(2), s. 55-67.

Jones, T. M. (1980). “Corporate Social-Responsibility Revisited, Redefined”. California Management Review, 22(3), s. 59-67.

Kotler, P. ve Lee, N. (2005). Corporate Social Responsibility: Doing the Most Good for Your Company and Your Cause. Hoboken, New Jersey: John Wiley \& Sons.

Lantos, G. P. (2001). "The Boundaries of Strategic Corporate Social Responsibility”. The Journal of Consumer Marketing, 18(7), s. 595-649.

McWilliams, A. ve Siegel, D. (2001). "Corporate Social Responsibility: A Theory of the Firm Perspective". Academy of Management Review, 26(1), s. 117-127.

McWilliams, A., Siegel, D. S. ve Wright, P. M. (2006). “Corporate Social Responsibility: Strategic Implications”. Journal of Management Studies, 43(1), s. 1-18.

Özüpek, M. N. (2008). "Sosyal Sorumluluk”. (Ed.: A. Kalender ve M. Fidan). Halkla İlişkiler, (251-289), Konya: Tablet Yayınları. 
Roberts, R. W. (1992). "Determinants of Corporate Social Responsibility Disclosure: An Application of Stakeholder Theory". Accounting Organizations and Society, 17(6), s. 595-612.

Sönmez, B. (2014). Sosyal Sorumluluk Projelerinin Isşletme Imajına Etkisi: Yerli Turistler Üzerinde Bir Araştırma. Yayımlanmamış Yüksek Lisans Tezi, Balıkesir Üniversitesi Sosyal Bilimler Enstitüsü, Balıkesir.

Sönmez, F. (2004). “İşletmelerin Sosyal Sorumluluğu”. Yaklaşım Dergisi, 133(1), s. 476-490.

TDK (2015). “Türk Dil Kurumu Güncel Türkçe Sözlük”. http://tdk.gov.tr/index.php?option=com_gts\&view=gts (Erişim Tarihi: 13.03.2015)

Torlak, Ö. (2013a). "Kurumsal Sosyal Sorumluluk Alanları”. (Ed.: M. C. Öztürk). Kurumsal Sosyal Sorumluluk, (s. 32-48), Eskişehir: Anadolu Üniversitesi Yayınları No: 3021.

Torlak, Ö. (2013b). “Kurumsal Sosyal Sorumluluk ve Pazarlama Uygulamaları”. (Ed.: M. C. Öztürk). Kurumsal Sosyal Sorumluluk, (s. 72-89), Eskişehir: Anadolu Üniversitesi Yayınları No: 3021.

Vural, Z. B. A. ve Coşkun, G. (2011). "Kurumsal Sosyal Sorumluluk ve Etik”. Gümüşhane Üniversitesi İletişim Fakültesi Elektronik Dergisi, 1(1), s. 61-87. 